\title{
Media Pembelajaran Realia
}

\author{
Muhammad Ullil Fahri \\ muhammad.fahri001@binus.ac.id \\ https://ullilfahri.skb.ovh/
}

Realia media, yaitu semua media nyata di dalam kelas, tetapi dapat digunakan sebagai kegiatan observasi di lingkungan [1]. media pembelajaran yang langsung dapat di observasi oleh siswa dinamakan media realia. Pengamatan (Obsevarsi) adalah kegiatan mengamati suatu objek secara langsung dan terperinci untuk mencari informasi tentang objek tersebut [2]. Dengan menggunakan metode observasi diharapkan siswa dapat mengenal secara langsung dari suatu objek yang ditunjukan oleh guru. Pengertian lainya dari Media realia adalah benda asli dari suatu benda dalam suatu keadaan kehidupan yang utuh dan dapat digunakan, dalam ukuran aslinya dan dapat dikenali sebagai bentuk aslinya. [1] . Contoh dalam pengenalan komputer, guru langsung menunjukan bentuk asli dari komputer dengan membawa siswa ke lab komputer. Dengan mengetahui bentuk asli dari komputer timbul pemahaman lebih dibandingkan guru harus membuat sebuah cerita narasi yang menggambarkan bentuk dari komputer.

Gambar 1. Contoh Media Realia

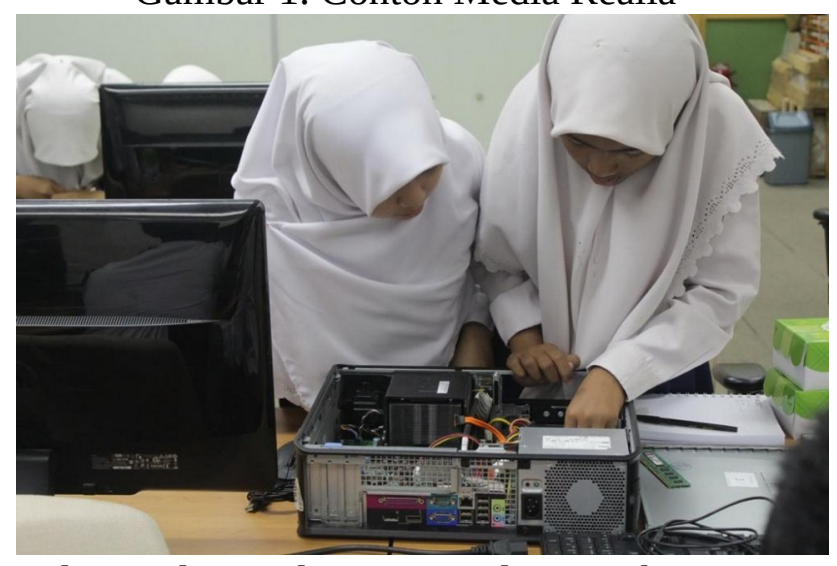

media realia pada mata pelajaran komputer. Dimana siswa di ajak melihat langsung cara merakit komputer. Dengan tujuan mahasiswa mengenal perangkat keras komputer.

Kesimpulan dari media realia adalah [1] :

1. Media nyata atau benda nyata yang dapat dilihat, disentuh, dipegang dan dimanipulas.

2. Media realia adalah media yang tidak berubah atau asli dan tidak berupa tiruan atau model dari benda nyata.

3. Media realia dapat berupa manusia, mata uang, tumbuhan, hewan, batuan, air, tanah, benda dan makanan

Merujuk pada pendapat Rusman (2005: 2) media realia, yaitu semua media nyata yang ada di lingkungan alam, baik digunakan dalam kondisi kehidupan maupun dilestarikan. Misalnya tumbuhan, batu, hewan, serangga, benda, air, sawah, makanan dan sebagainya. Hal lain yang mengemukakan kepada Halamik (1989: 133) bahwa media realia adalah suatu benda yang dapat digunakan untuk membantu pengajaran seperti bunga, batu, koran, dll. Yang bisa dilakukan oleh siswa atau guru [1]. Dapat dilihat media realia ini tidak semua dapat diterapkan, hal - hal yang memungkinkan saja untuk diterapkan media realia. Tidak mungkin kita ketika ada pelajaran yang menjelaskan tentang bulan lalu kita membawa bulan asli kedalam kelas. Hal ini dapat disiasati dengan mengganti dengan bentuk bulan palsu yang menyerupai.

\section{Gambar 2. Siswa Mengamati Tumbuhan}

Pada gambar 2 merupakan salah satu penerapan media pembelajaran realia. Dimana siswa di ajak ikut ke lapangan dan melakukan observasi secara mandiri tentang tumbuhan. Tentunya hal ini menarik perhatian siswa karena 


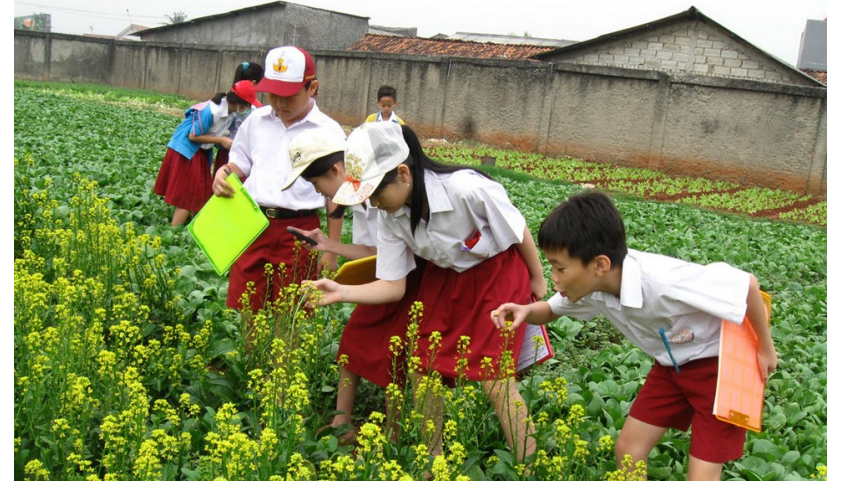

mereka diajak langsung untuk melihat detail tumbuhan yang dijelaskan oleh guru.

Berdasarkan Penelitian Tindakan Kelas yang dilakukan, secara umum dapat disimpulkan bahwa penerapan media realia dapat meningkatkan hasil belajar siswa kelas 1 SDN 14 Leminang.[3]. Diatas adalah penelitian yang telah dilakukan pada kelas I SD dengan mata pelajaran matematika. Terlihat bahwa media realia dapat meningkatkan hasil belajar siswa SD I. Dengan menggunakan media realia, siswa dapat memperagakan bilangan puluhan dan ratusan dengan secara langsung menggunakan media yang digunakan. Dengan mengguakan media realias siswa dapat mengembangkan kemampuannya untuk mengamati semua objek yang terlibat dalam proses pembelajaran dan menarik kesimpulan yang diharapkan. Penggunaan Realia Media berdampak pada: Perhatian siswa lebih terfokus, Proses belajar siswa lebih tertuju pada materi yang dipelajari, Pengalaman dan kesan sebagai hasil belajar lebih melekat pada siswa [3]. Dengan contoh diatas dapat dilihat siswa di ajak memperagakan bilangan puluhan dan ratusan secara langsung.

Kelebihan dalam menggunakan media realia [4] :

1. Dapat memberikan kesempatan terbesar bagi siswa untuk mempelajari sesuatu atau mengerjakan tugas dalam situasi nyata.

2. Meberikan siswa kesempatan untuk mengalami situasi nyata bagi diri mereka sendiri dan melatih keterampilan mereka dengan menggunakan sebanyak mungkin organ sensorik (Indra).

Kelemahan Media Realia [4] :

1. Membawa siswa ke berbagai tempat di luar sekolah terkadang melibatkan resiko berupa kecelakaan dan sejenisnya.

2. Terkadang biaya yang dikeluarkan untuk pengadaan berbagai benda nyata tidak sedikit, apalagi dengan kemungkinan kerusakan dalam penggunaannya. Tidak selalu mampu menyajikan semua gambaran benda nyata, seperti memperbesar, memotong dan menggambar bagian demi bagian, sehingga pengajaran juga harus didukung dengan media lain.

Berikut langkah - langkah penggunaan media realia [5] :

1. Sediakan benda-benda nyata yang berhubungan dengan bahan ajar.

2. Gunakan benda nyata ini dalam proses pembelajaran di kelas. Siswa mendapatkan pengalaman langsung dari benda-benda tersebut.

3. Ajaklah siswa mengamati secara langsung, kemudian berbicara dengan teman mereka tentang materi yang diajarkan.

4. Setelah mengamati dan berdiskusi, siswa dengan bimbingan guru dapat menyimpulkan materi yang diajarkan. 


\section{DAFTAR PUSTAKA}

[1] Jejakpendidikan, “Media Realia,” 2017. http://www.jejakpendidikan.com/2017/03/mediarealia.html\#: :text=Menurut Udin S.W (Patty\%2C 2007,merupakan objek nyata suatu benda.\&text=Menggunakan benda nyata dalam proses,lebih memahami materi yang diajarkan. (accessed Nov. 10, 2020).

[2] “Pengertian Observasi (Lengkap): Arti, Ciri-ciri dan Jenisnya.” https://saintif.com/observasiadalah/ (accessed Nov. 10, 2020).

[3] T. S. Asngadah, Zainuddin, "PENINGKATAN HASIL BELAJAR SISWA MENGGUNAKAN MEDIA REALIA PADA PEMBELAJARAN MATEMATIKA KELAS I SD.”

[4] E. D. CAHYO, "Pengertian Media Realia Kelebihan dan Kelemahan Media Realia,” 2012. https://text-id.123dok.com/document/1y9g9rjwq-pengertian-media-realia-kelebihan-dankelemahan-media-realia.html (accessed Nov. 10, 2020).

[5] R. S. NUGRAHA, "Media Pembelajaran Realia,” 2018.

https://www.tintapendidikanindonesia.com/2018/01/media-pembelajaran-realia.html (accessed Nov. 10, 2020). 